\title{
Motion in the north Iceland volcanic rift zone accommo- dated by bookshelf faulting
}

\author{
Robert. G. Green ${ }^{\star}$, Robert. S. White \& Tim Greenfield
}

Published article: Green, R. G., White, R. S., Greenfield, T. Motion in the north Iceland volcanic rift zone accommodated by bookshelf faulting. NatureGeosci. 7, 29-33 (2014)

\author{
Or contact author (rgcg3@cam.ac.uk) for copy of article
}

Crustal extension is segmented at all constructive plate boundaries, occurring on length scales of $10-1,000$ kilometres $^{[1]}$. Where these spreading segments are offset, extensional motion must transfer from one segment to another. In classical plate tectonics, midocean ridges are offset by transform faults, but smaller "non-transform" offsets exist between slightly overlapping spreading centres which accommodate shear by a variety of geometries ${ }^{[2]}$. Here we reveal the nature by which the transform motion is accommodated between two such rift segments in north Iceland. Precise location and characterisation of micro-earthquakes identifies a series of faults sub-parallel to the rift fabric, and source mechanisms reveal left-lateral strike-slip motion on the faults. This is consistent with the motion being accommodated by a bookshelf faulting mechanism, named after its resemblance to a tilting row of books on a shelf $f^{[3]}$. Right-lateral transform motion due to the offset between the two overlapping rift segments imposes a shear across this zone. This causes left-lateral movement on the series of bookshelf strike-slip faults and clockwise rotations about a vertical axis of the faults and intervening crustal blocks. The identified faults probably reactivated crustal weaknesses along the rift fabric (dyke intrusion parallel to the rift axis) and have since rotated $\sim 15^{\circ}$ clockwise into their present orientation. This reactivation of preexisting rift-parallel weaknesses is in contrast with midocean ridge transform faults, and is an important illustration of a "non-transform" offset accommodating shear between overlapping spreading segments.

The rift zones of the accretionary plate boundary in Iceland comprise en echelon stepping segments, each of which forms a distinct volcanic system with a central volcano and bisecting fissure swarm $^{[4]}$. They are typically about $15 \mathrm{~km}$ wide. Discontinuous accretion of the brittle upper crust occurs within these volcanic segments, with short rifting episodes characterised by dyke intrusion, fissure eruptions and normal faulting. The inter-rift phase of the cycle in the upper crust is largely amagmatic.

In the Northern Volcanic Zone, the rift zone in the north-east of Iceland, the rift segments themselves are currently relatively aseismic in the upper crust, except for the geothermal area to the south-east of Askja caldera lake. However, focussed and intense microseismicity highlights a deforming zone between the en echelon stepping Askja and Kverkfjöll volcanic rift segments (Figure 1). These microearthquakes are spatially and temporally clustered as swarms lasting from one week to one month, and delineate NE-SW striking faults between $2-6 \mathrm{~km}$ depth (Figure 2). In cross section, the seismicity shows an abrupt boundary at $6-7 \mathrm{~km}$ depth (Figure $1 \mathrm{~b}$ ). We interpret this as marking the brittle-ductile transition of the crust, above which all the brittle faulting occurs.

Seismic data collected from a local seismometer array for this study has excellent signal-to-noise ratio and yielded 214 first motion polarity fault plane solutions which are constrained well by observations distributed across the focal sphere (Figure 3). The solutions are remarkably consistent (Supplementary Figures 1-4), with robust left-lateral strike-slip mechanisms and a tight spread of fault planes which matches within error the epicentral trends of the swarms (Figure 2). Throughout the study period of 2009 to 2012 we captured motion on a series of left-lateral strike-slip faults in the relay zone between the extensional Askja and Kverkfjöll volcanic rift segments. The sub-parallel faults trend at $040^{\circ}-$ $045^{\circ}$ and are oblique to the surface fractures and extensional fissures in the segments on either side, which trend at an average of $025^{\circ}{ }^{[5],[6]}$ (Figure 2a rose diagrams). These surface features within the rift zones are occasionally normal fault scarps, but are usually generated by extensional fissuring above intruded dykes. The entire region has been resurfaced by extensive post-glacial lava flows, many of which are younger than 4,500 years $^{[7]}$. Since this resurfacing, on-going dyke intrusion and extension in the rift zones has frequently caused surface failure (Figure 1), whereas the strike-slip faults in the relay zone have not caused any discernible surface fracturing.

A significant implication of the left-lateral strike-slip faults is that slip on them requires the crustal blocks in the relay zone to rotate clockwise about a vertical axis via the bookshelf mechanism ${ }^{[3]}$ (Figure 4). The thrust faulting at the end of the westernmost fault (black fault plane solutions on Figure 2) lends support to this rotation mechanism because a similar scenario is observed where strike-slip faults terminate in the continents ${ }^{[8]}$. Displacement on thrust faults perpendicular to the ends of continental bookshelf strike-slip faults dies out with distance from the main fault, which is interpreted to represent the local rotational motions associated with the strike-slip faulting.

In Iceland the North American and Eurasian plates spread apart at an azimuth of $106(\mathrm{NUVEL}-1 \mathrm{~A})^{[9]}$ at $18.2 \mathrm{~mm} / \mathrm{a}$. Along segments of the plate boundary that are oblique to this spreading direction, it is common to find volcanism and strike-slip faulting in close proximity. In both the Grímsey Oblique Rift ${ }^{[10]}$ and the Reykjanes Peninsula Rift ${ }^{[11]}$ (Figure 1 inset), bookshelf rotations from slip on arrays of strike-slip faults transverse to the plate boundary occur in close association with volcanic fissuring. Dyking accommodates the divergent component of the spreading 
and the bookshelf rotations take up the additional transcurrent component ${ }^{[4]}$. In the Northern Volcanic Zone, however, motion at the plate boundary is almost entirely divergent as the rift axis is close to perpendicular to the spreading direction. Extensionally controlled strike-slip faulting is therefore unexpected in this rift setting, as dyking and normal faulting should be sufficient to accommodate extension.

The seismic fault planes within this relay zone strike at approximately $60^{\circ}$ to the regional spreading direction of $106^{\circ}$, which we assume represents the minimum stress direction $\sigma_{3}$. This might be used to argue that they respond simply to extensional stresses, as $60^{\circ}$ is within the range of angles at which homogenous rock breaks and faults initiate. However, for these faults to accommodate plate spreading then further deformation would have to be partitioned into another component, either as conjugate strike-slip faulting, or as extensional fracturing and dyking as in the Grímsey Oblique Rift and the Reykjanes Peninsula Rift. Such additional faulting is not seen between the Askja and Kverkfjöll segments, and there is a lack of post-glacial volcanic fissures or fractures at the surface which might have indicated such activity. Even if the faulting we observe did account for $100 \%$ accommodation of the extensional regional stresses, the focussed nature of the microseismicity would remain unexplained. If tectonic spreading were occurring between the rift segments, it should extend along the entire region between the segments, yet microseismicity occurs only adjacent to the region where the active Kverkfjöll segment is best understood to terminate at the present day ${ }^{[6]}$.

These arguments suggest that the bookshelf motions are not responding solely to regional tectonic extension, but are controlled by an externally imposed shear ${ }^{[3]}$ due to the concentrated strain where one segment (Kverkfjöll) terminates and the extension is transferred to the adjacent (Askja) segment. The focussed spreading must step left to the Askja segment at the latitude of the relay zone, rather than being partitioned between both the Askja and Kverkfjöll segments, as it is to the south. As a result of this offset in spreading, differential motion must occur between crustal material to the north and to the south of the relay zone, thereby imposing shear (Figure 4). The simultaneous motion on this array of parallel left-lateral strike-slip faults, and the collective rotation of the crustal blocks in-between the faults can accommodate this externally imposed right-lateral shear. This relay zone is therefore in an overall sense a transform zone with right-lateral motion.

Since 1974 enhancement of the country-wide seismic network has made it possible to record small earthquakes from this area $^{[12],[13]}$, and since 2005 to resolve strike-slip activity in association with lineated swarms ${ }^{[14],[5]}$. We infer therefore that the seismicity on left-lateral strike-slip faults in the relay zone has been persistent not only during the 2009 - 2012 duration of our local seismic survey, but has been on-going for at least the last two to four decades over which there has been sufficient seismic monitoring to detect it.

Such persistent seismicity is not observed at all en echelon steps of Icelandic rift segments, but between the Askja and Kverkfjöll segments the trend of the rift axis changes from NE-SW to N-S (Figure 1 inset). The left-stepping shift in localised crustal spreading is more significant than at other segment boundaries and sets up stresses that shear this relay zone in a right-lateral sense. The area also lies within a diffuse belt of WNW oriented fractures between the Krafla and Kverkfjöll segments (Figure 1) which suggest transform motion within the belt ${ }^{[15]}$. However rather than forming a focussed $\mathrm{E}-\mathrm{W}$ transform fault between the segments, small strike-slip faults form transverse to the transform. The series of faults slip and rotate via the bookshelf mechanism, thereby accommodating the shear (Figure 4), which we assume to be aligned with spreading at $106^{\circ}$.

A similar bookshelf faulting scenario is observed in the eastern Transverse Ranges of the USA, where the crust between the locked San Andreas and San Jacinto faults is sheared in a right lateral sense, and breaks along left-lateral strike-slip faults transverse to the shear ${ }^{[16]}$. In the South Iceland Seismic Zone (SISZ) (Figure 1) bookshelf faulting also accommodates $E-W$ shear. The crust breaks perpendicular to the shear direction on N-S right-lateral strike-slip faults, and the associated anticlockwise rotations accommodate the left-lateral shear ${ }^{[13],[17]}$.

Within the Askja-Kverkfjöll relay zone the faults are orientated at approximately $040^{\circ}$, which is only $15^{\circ}$ oblique to the surface features $\left(\sim 025^{\circ}\right)$ in the fissure swarms on either side, and unlike the SISZ, is not perpendicular to the shear. This raises the question as to whether the faults are picking up and rotating pre-existing weaknesses in the crust, or are fresh fractures breaking in an energetically favourable orientation.

If these are long-term faults which initiated on pre-existing crustal weaknesses and rotated these planes clockwise to their currently active position, then the orientation at which they broke is likely to have been along the original pervasive dyke intrusion fabric. Given that this intrusion fabric provides ideal weak subvertical slip planes, and that the seismic faults are relatively close to that fabric it seems more probable that the strike-slip faults formed initially along the rift fabric $\left(\text { at } \sim 025^{\circ}\right)^{[5],[6]}$ than breaking fractures at fresh orientations. We infer that the bookshelf faults would then have progressively slipped and rotated $15^{\circ} \mathrm{clockwise}$ into their present orientation of $040^{\circ}$. A similar rotation of preexisting ridge parallel faults has been inferred between overlapping spreading centres in the oceans ${ }^{[18],[19]}$.

If this inference is correct, block models can be used to estimate the present rotation and slip rates on the faults ${ }^{[20]}$. Using the method of Copley \& Jackson 2006, assuming a bookshelf block size of 15 by $2 \mathrm{~km}$ (Figure 4), we calculate a slip rate on each fault of $0.9-1.8 \mathrm{~mm} / \mathrm{a}$ and block rotation rates of $20-40^{\circ} / \mathrm{Myr}$. For the strike-slip faults to rotate from the rift fabric to their present orientation would then have taken $0.4-0.8 \mathrm{Myr}$. This rate is rapid compared to commonly measured continental block rotations but due to the narrow zone and high shear is comparable to rotation rates in observed oceanic microplates ${ }^{[21]}$.

In summary we record focussed transform motion between offset segments of the rift zone in northern Iceland. The right-lateral shear motion is accommodated by 'bookshelf' faulting: left-lateral slip on strike-slip faults sub-parallel to the rift fabric, with clockwise rotations about a vertical axis. Should the shear have been prolonged over rift cycles of at least the past $0.4-0.8 \mathrm{Myr}$ then we conclude that the bookshelf motions would have rotated the faults $15^{\circ}$ from the orientation of the original fabric to their present oblique trends of $040^{\circ}$. Why this occurs is most likely a result of the strength of the crustal anisotropy created by the pervasive dyke intrusion fabric along the rift. The absence of any upper crustal tectonic and magmatic activity within the rift segments during the instrumental period demonstrates that these segments are in an inter-rift period. Seismicity in the mid-lower crust, however, shows evidence of on-going magmatic activity ${ }^{[22],[23]}$, which may be accommodating extension within the rift zones by intrusion in the lower crust. The stresses generated by the rift segment extension are then responsible for the seismic activity and shear occurring in the relay zone between rift segments.

Seismic data used in this study were acquired using a network of between 22 to 40 Güralp 6TD and Güralp ESPD seismometers from January 2009 to September 2012. Station density within the network has increased gradually, though the network footprint and azimuthal coverage has changed little. Figure 1 displays the network configuration as it was for the winter of 2011-2012. Automated detection and location of seismic events in our data set is achieved using the Coalescence Microseismic Mapping (CMM) technique ${ }^{[24]}$. The program migrates seismic energy from each receiver back into a $3 \mathrm{D}$ subsurface grid, computing a coalescence function through time across the grid nodes. A peak in the coalescence function defines a grid node location and origin time which best fits the seismic energy arriving at all the receivers. A more complete explanation of the CMM technique is available in Tarasewicz et al. ${ }^{[25]}$ and Drew ${ }^{[24]}$. 
Automated locations allowed seismic swarms to be identified for further processing. $\mathrm{P}$ and $\mathrm{S}$ wave arrival times were refined manually, and events located using NonLinLoc, a program for probabilistic non-linear earthquake location ${ }^{[26]}$. For this we used a linear gradient velocity model ${ }^{[27]}$ derived from local seismic experiments in the Askja region and the RRISP experiment. Earthquake picks on the easternmost strike-slip fault are from Martens \& White ${ }^{[28]}$.

Double difference relocations were then computed using HypoDD ${ }^{[29]}$. The layered velocity model required by the program was generated by an approximation to the gradient model. This process tightens hypocentral locations and brings fault lineations into focus. The complete hypocentre set is listed in the supplementary material.

The typical accuracy of manual picks was $0.01 \mathrm{~s}$ (P-waves) to $0.05 \mathrm{~s}$ (S-waves) and initial location errors from NonLinLoc were of the order of $1 \mathrm{~km}$ with an RMS misfit of 0.1-0.2 s. Relocation using double difference techniques then markedly sharpened the clusters and reduced hypocentral errors to typically $20-50 \mathrm{~m}$. Ray takeoff angles from the absolute event locations were used to generate first motion polarity fault plane solutions using FPFIT $^{[30]}$. Figure 3 displays an example of a typical fault plane solution generated using FPFIT. All fault plane solutions from the main swarms are shown in Supplementary Figures 1-4.

Fault trends were defined by fitting the trend of microearthquake epicentres using a least squares regression with a bisquare weighting function to reduce the effect of outlying events on the best fit trend. The error in the fault trends was quantified as twice the standard error of the gradient from the regression function. Within uncertainties, the strikes of all the faults are the same, and the azimuths of the epicentres (for the 6 well lineated swarms in Figure 2) match directions of the fault planes inferred from fault plane solutions.

When estimating rotation rates using the block model of Copley and Jackson ${ }^{[20]}$, the region affected by persistent seismicity (Figure 1) was used to define the width of the deforming transform zone as $15 \mathrm{~km}$. The separation between seismically active faults was approximately $2 \mathrm{~km}$, and the shear direction was taken to be the plate spreading vector of $106^{\circ}(\text { NUVEL-1A })^{[9]}$. Shear estimates are based on the geometry of the volcanic systems of Einarsson \& Saemundsson ${ }^{[12]}$. To the north of the faulted zone all spreading has been offset west to the segments of Askja, Fremrinámur and Krafla, so the crust immediately north of the relay zone has an eastwards motion at full spreading velocity (Figure 4). This assumes that the active Kverkfjöll spreading segment terminates as mapped $^{[12]}$, along the lines of evidence discussed by Hjartardóttir et al. ${ }^{[6]}$. Immediately south of the faulted zone the eastward motion with respect to the North American plate depends on the distribution of spreading between the Askja and Kverkfjöll segments. A range of $\frac{1}{4}$ to $\frac{1}{2}$ of the full spreading rate accommodated by Kverkfjöll is used to calculate the range of shear and rotation rates.

\section{Received 24 April 2013; accepted 23 October 2013; \\ published online 1 December 2013}

\section{References}

[1] Macdonald, K. C. et al. A new view of the mid-ocean ridge from the behaviour of ridge-axis discontinuities. Nature $\mathbf{3 3 5}$, 217-225 (1988).

[2] Grindlay, N. R., Fox, P. J. \& MacDonald, K. C. Second-order ridge axis discontinuities in the south Atlantic: Morphology, structure, and evolution. Marine Geophysical Researches 13, 21-49 (1991).
[3] Mandl, G. Tectonic deformation by rotating parallel faults: the "bookshelf" mechanism. Tectonophysics 141, 277-316 (1987).

[4] Einarsson, P. Plate boundaries, rifts and transforms in Iceland. Jökull 58, 277-316 (2008).

[5] Hjartardóttir, A., Einarsson, P. \& Sigurdsson, H. The fissure swarm of the Askja volcanic system along the divergent plate boundary of N Iceland. Bulletin of Volcanology 71, 961-975 (2009)

[6] Hjartardóttir, A. R. \& Einarsson, P. The Kverkfjöll fissure swarm and the eastern boundary of the Northern Volcanic Rift Zone, Iceland. Bulletin of Volcanology 74, 143-162 (2012).

[7] Sigvaldason, A. K., G. E. \& Nilsson, M. Effect of glacier loading deloading on volcanism-postglacial volcanic productionrate of the Dyngjufjoll area, central Iceland. Bull. Volcanol. 54, 385 - 392 (1992).

[8] Bayasgalan, A., Jackson, J., Ritz, J.-F. \& Carretier, S. Field examples of strike-slip fault terminations in Mongolia and their tectonic significance. Tectonics 18, 394-411 (1999).

[9] DeMets, G. G. A. D. F., R. \& Stein, S. Effect of recent revisions to the geomagnetic reversal timescale on estimates of current plate motions. Geophys. Res. Lett. 21, 2191-2194 (1994).

[10] Rögnvaldsson, S. T., Guðmundsson, A. \& Slunga, R. Seismotectonic analysis of the Tjörnes Fracture Zone, an active transform fault in north Iceland. Journal of Geophysical Research 103, 117-130 (1998).

[11] Árnadóttir, T. Coseismic stress changes and crustal deformation on the Reykjanes Peninsula due to triggered earthquakes on 17 June 2000. Journal of Geophysical Research 109, B09307 (2004).

[12] Einarsson, P. \& Saemundsson, K. Earthquake epicenters 1982-1985 and volcanic systems in Iceland (Map) (Menningardjóður, Reykjavík, 1987).

[13] Einarsson, P. Earthquakes and present-day tectonism in Iceland. Tectonophysics 189, 261-279 (1991).

[14] Porbjarnardóttir, B. S., Guðmundsson, G. B., Hjaltadóttir, S. \& Roberts, M. J. Seismicity in Iceland during 2006. Jokull 57, 45-60 (2007).

[15] Hjartardóttir, A. Fissure swarms of the Northern Volcanic Rift Zone, Iceland. Ph.D. thesis (Univ. Iceland, 2013).

[16] Nicholson, S. L. W. P., C. \& Sykes, L. R. Journal of Geophysical Research 91, 4391-4908.

[17] Einarsson, P. Mapping of Holocene surface ruptures in the South Iceland Seismic Zone. Jökull 60, 121-138 (2010).

[18] Searle, R. C. \& Hey, R. N. Gloria observations of the propagating rift at $95.50 \mathrm{~W}$ on the Cocos-Nazca Spreading Center. Journal of Geophysical Research 88, 6433 (1983).

[19] Wetzel, L. R., Wiens, D. A. \& Kleinrock, M. C. Evidence from earthquakes for bookshelf faulting at large non-transform ridge offsets. Nature 362, 235-237 (1993).

[20] Copley, A. \& Jackson, J. Active tectonics of the TurkishIranian plateau. Tectonics 25, TC6006 (2006).

[21] Larson, R. L. e. a. Roller-bearing tectonic evolution of the Juan Fernandez microplate. Nature 356, 571-575 (1992).

[22] Soosalu, H. e. a. Lower-crustal earthquakes caused by the magma movement beneath Askja volcano on the north Iceland rift. Bull. Volcanol. 72, 55-62 (2009).

[23] Key, J., White, R. S., Soosalu, H. \& Jakobsdóttir, S. S. Multiple melt injection along a spreading segment at Askja, Iceland. Geophysical Research Letters 38, 1-5 (2011).

[24] Drew, W. R. S. T. F., J. \& Tarasewicz, J. Coalescence microseismic mapping. Geophysical Journal International 195, 1773-1785 (2013). 
[25] Tarasewicz, J., Brandsdóttir, B., White, R. S., Hensch, M. \& Porbjarnardóttir, B. Using microearthquakes to track repeated magma intrusions beneath the Eyjafjallajökull stratovolcano, Iceland. Journal of Geophysical Research 117, B00C06 (2012).

[26] Lomax, V. J. V. P., A. \& Berge, C. Advances in Seismic Event Location. Ph.D. thesis (Kluwer, 2000).

[27] Key, J. Tracking Melt with Lower Crustal Earthquakes at Askja , Iceland. Ph.D. thesis (Univ. Cambridge, 2011).

[28] Martens, H. R. \& White, R. S. Triggering of microearthquakes in Iceland by volatiles released from a dyke intrusion. Geophysical Journal International 194, 1738-1754 (2013).

[29] Waldhauser, F. \& Ellsworth, W. A double-difference earthquake location algorithm: Method and application to the northern Hayward fault, California. Bull. Seismol. Soc. Am. 90, 1353-1368 (2000).

[30] Reasenberg, P. \& Oppenheimer, D. FPFIT, FPPLOT, FPPAGE: Fortran Computer Programs for Calculating and Displaying Earthquake Fault-Plane Solutions. Tech. Rep., U.S. Geological Survey (1985).

\section{Acknowledgements}

Seismometers were borrowed from the Natural Environment Research Council SEIS-UK (loans 914 and 968), and the work funded by a research grant and studentships from the NERC and Shell. We thank Sveinbjörn Steinpórsson, Heidi Soosalu and all those who have assisted in fieldwork in Iceland since 2009. We are grateful to Ásta Rut Hjartardóttir and Páll Einarsson for providing raw data on fracture orientations and for helpful comments on the manuscript, and Alex Copley for advice. The Icelandic Meteorological Office kindly provided additional data from their seismometers in northeast Iceland. Dept. Earth Sciences, Cambridge contribution number ESC3000.

\section{Author Contributions}

All authors participated in data collection and the interpretation of results. Data processing of the microseismic swarms was carried out by R.G.G., with the addition of picks for the easternmost swarm by R.S.W. The manuscript was written by R.G.G and R.S.W.

\section{Additional information}

Supplementary information is available with the nature geoscience version.

\section{Competing financial interests}

The authors declare no competing financial interests. 


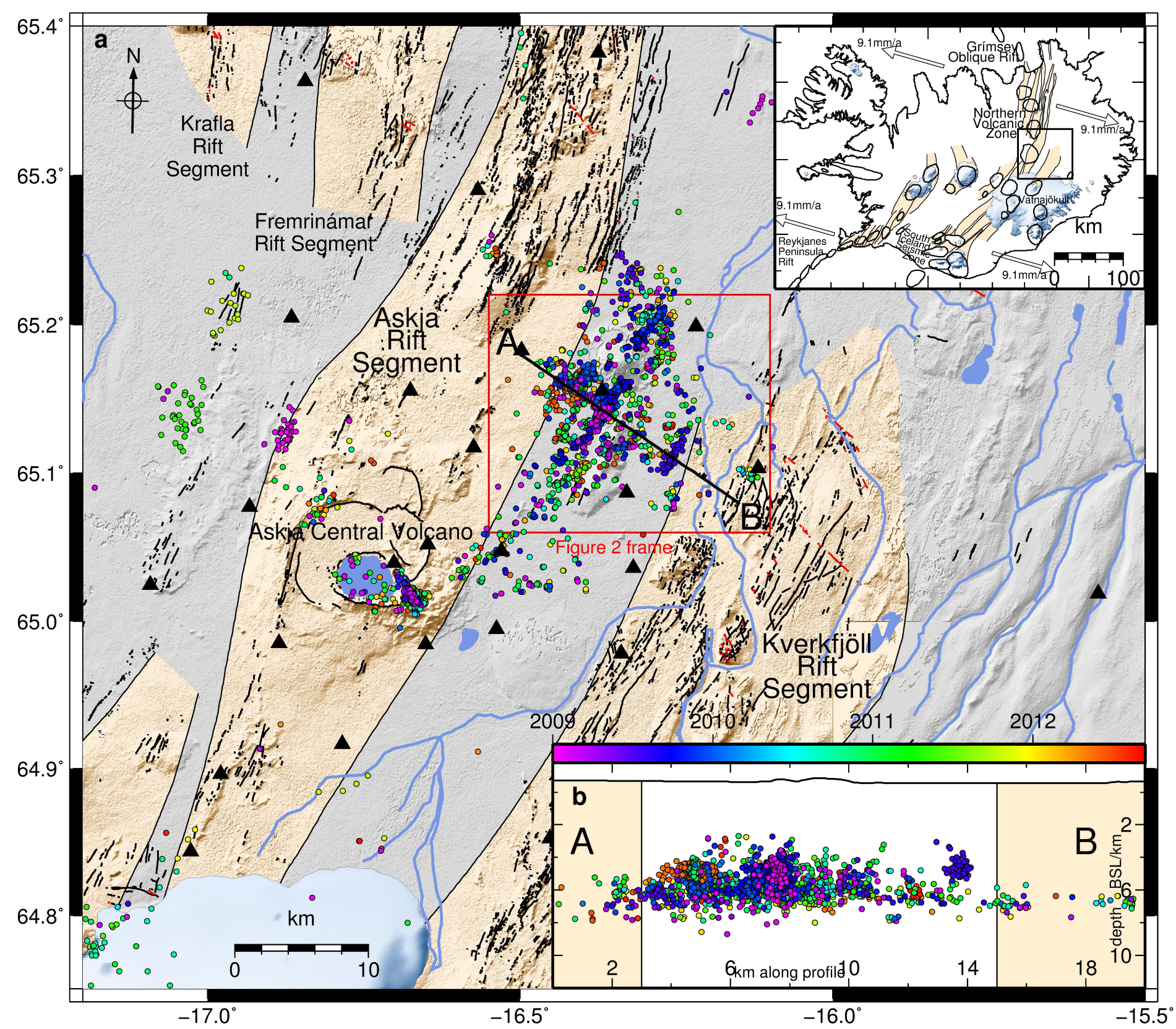

Figure 1: Automated microseismic event location; intense activity between volcanic rift segments a. Map of the southern end of the Northern Volcanic Zone (see inset for location), with topography in grey, permanent ice caps in blue-white, rivers and lakes in blue, tectonic fractures ${ }^{[5],[6],[15]}$ in black lines and active fissure swarms of the volcanic rift systems overlain in beige12. WNW oriented fractures5,6,15 are red lines. Black triangles are seismic stations and coloured circles show automatic hypocentral locations of microearthquakes ( $\mathrm{Mw} 0.5-3.0)$ at depths $<10 \mathrm{~km}$ below sea level (BSL). Events are coloured by date (see colour scale bar). b. Depth cross section of 2974 hypocentral locations projected from within $15 \mathrm{~km}$ onto profile A-B. 
C

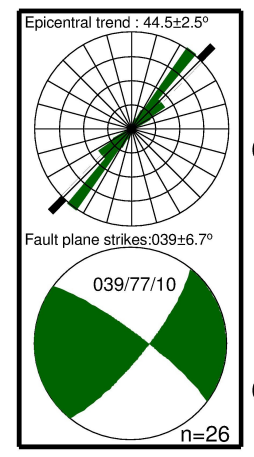

d

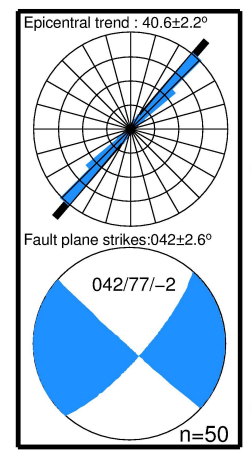

e

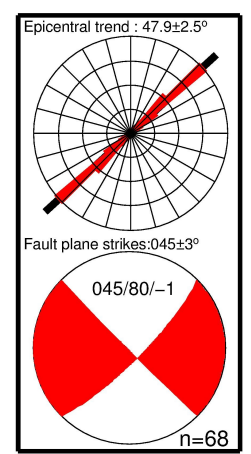

a
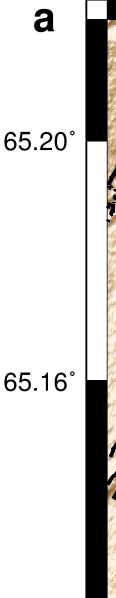

65.12

$65.08^{\circ}$

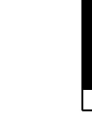

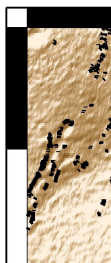

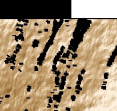

:
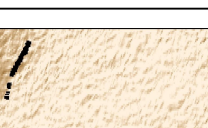

(1)

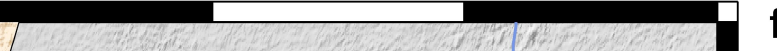

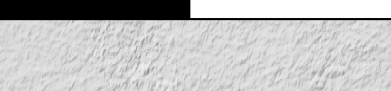

A

A $\quad 0$
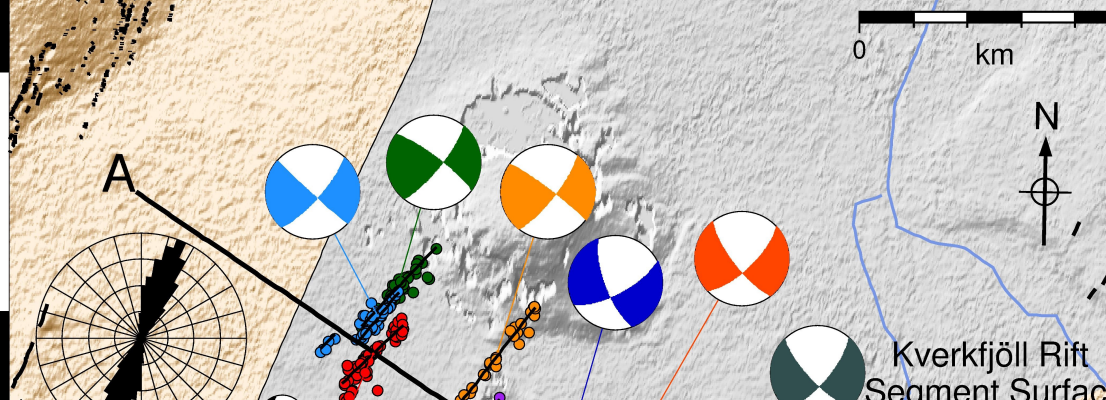

Askja Rict

Askja Rift

Surface

Fractures

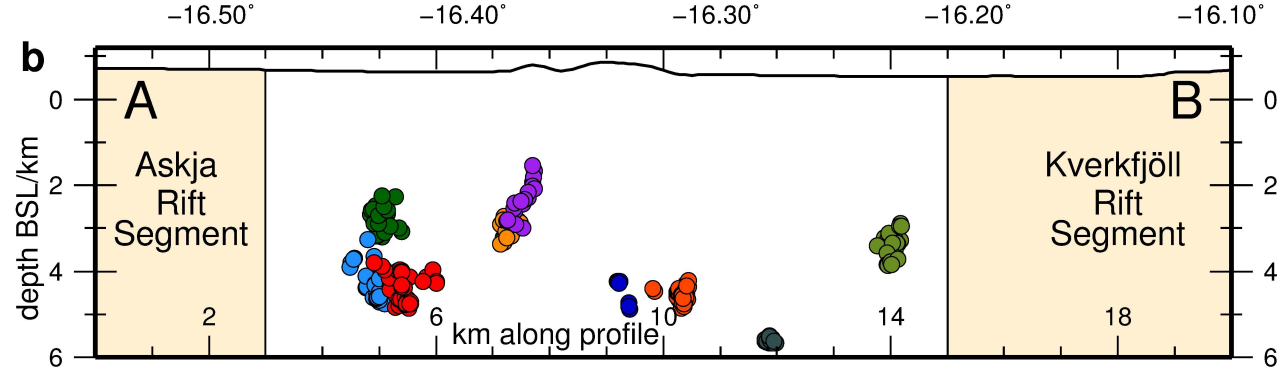

$65.16^{\circ}$

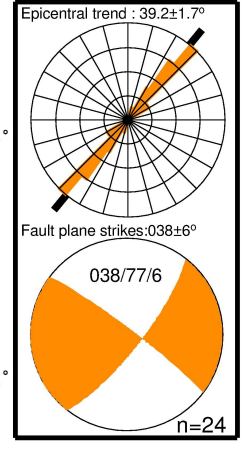

Kverkfjöll Rift

Fractures

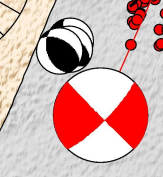

$\int_{0}$

48

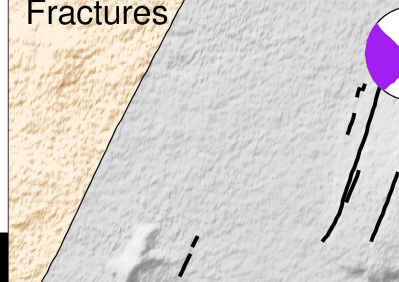

s?

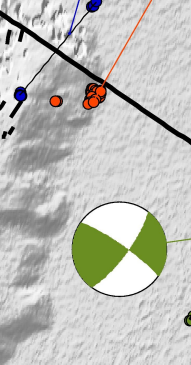

\section{Microseismic Events}
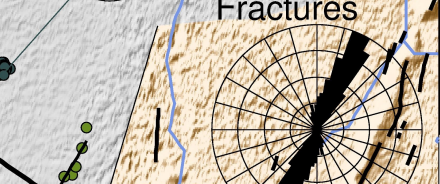

65.12

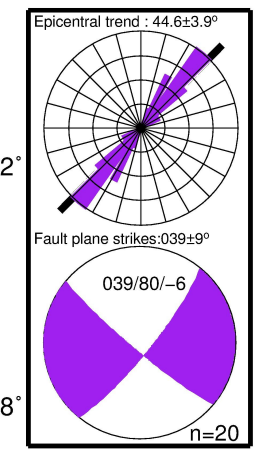

h

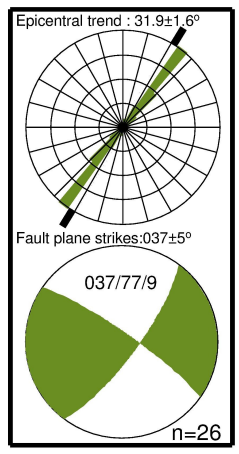

Figure 2: Sub-parallel array of left-lateral strike-slip faults in Askja - Kverkfjöll relay zone a. Relocated microearthquake swarms which delineate left-lateral strike-slip faults (black lines). Rose diagrams display surface fracture data ${ }^{[5],[6],[15]}$. Black fault plane solutions display three thrust microearthquakes. Background as in Figure 1. Red box on Figure 1 shows location. b. Depth cross section of hypocentres projected onto profile A-B. c-h. Fault statistics boxes. Rose diagrams compare the tight spread of strikes of fault plane solutions in each swarm (coloured sectors) with the epicentral trend (black external line). Error range is for 2 standard errors (95\% confidence interval). The coloured average fault plane solution (strike/dip/rake) corresponds to the relevant fault. $\mathrm{n}=$ number of events. 
16-May-2012 00:29:12.8
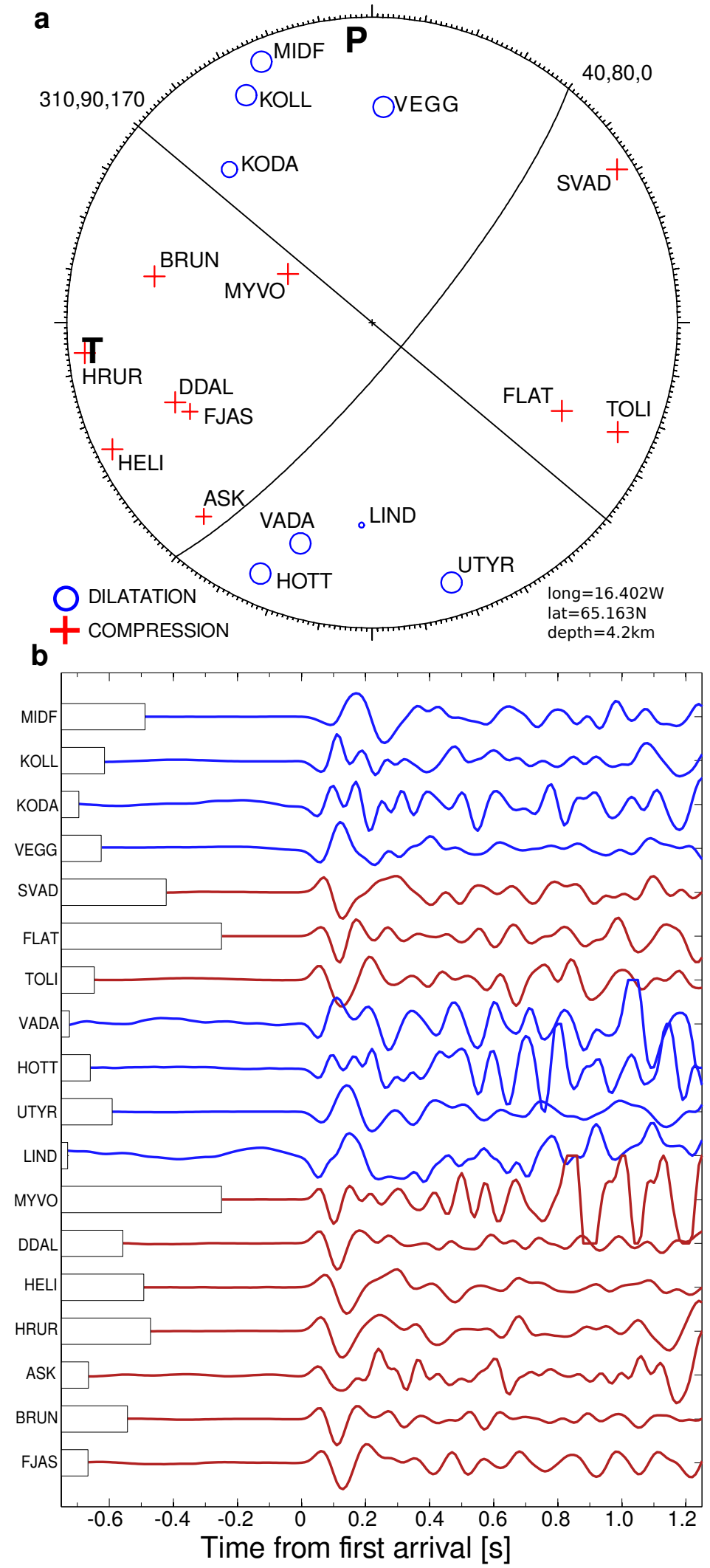

Figure 3: A typical strike-slip event; clear arrivals and a well constrained focal mechanism a. Best fit fault plane solution on a lower hemisphere stereographic equal area projection. Nodal planes are labelled 'strike,dip,rake'. Ray take off angles are plotted as blue circles or red crosses, with the size indicating the relative weight of each pick. Principle strain axes are marked by $\mathrm{P}$ and $\mathrm{T}$ b. Vertical component waveforms, bandpass filtered between $2-16 \mathrm{~Hz}$. Red waveforms are compressional arrivals, blue are dilatational. Waveforms have been trace-normalised to the same size. Relative differences between real seismogram amplitudes are shown by the different sizes of the rectangles to the left of each trace, with the highest amplitude arrival from MYVO. 


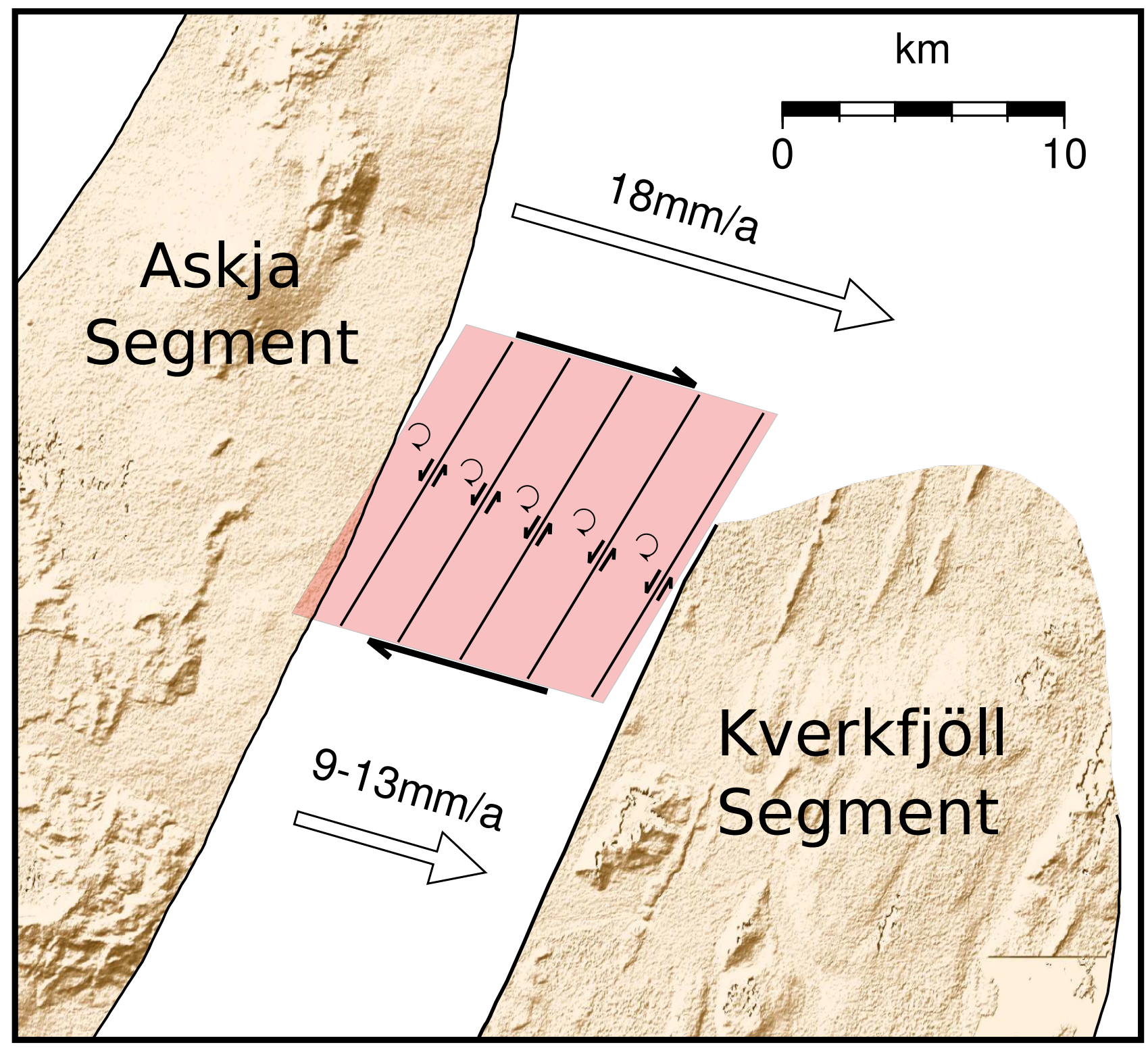

Figure 4: Right-lateral transform motion across the Askja-Kverkfjöll relay zone Schematic diagram showing the deforming relay zone as the red area, with crustal blocks approximately 15 by $2 \mathrm{~km}$ in size. The left-lateral strike-slip faults imply rightlateral shear across the zone, as shown by the closed arrows. Velocities in open arrows are relative to the North American plate. Background as in previous figures. 